\title{
THE PHENOMENON OF POLYGAMY OF CIVIL SERVANTS (PNS) IN AL MAQASHID AL SHARIA PERSPECTIVE: ANALYSIS STUDY OF GOVERNMENT REGULATION NO 45 OF 1990 IN KONAWE SOUTHEAST SULAWESI
}

\author{
Ipandang \\ Institut Agama Islam Negeri Kendari \\ Baruga, Kendari, Sulawesi Tenggara, Indonesia, 93563 \\ E-mail:ipandang@iainkendari.ac.id
}

\begin{tabular}{c|c|c}
\hline Received: & Revised: & Approved: \\
31/03/2021 & $09 / 06 / 2021$ & $16 / 06 / 2021$ \\
\hline
\end{tabular}

DOI : https:// doi.org/10.32332/akademika.v26i1.3203

\begin{abstract}
(). (1) (-)
The Phenomenon of Polygamy of Civil Servants (PNS) in Al Maqashid Al Sharia Perspective: Analysis Study of Government Regulation No 45 of 1990 in Konawe Southeast Sulawesi Licensed Under a Creative Commons Attribution-ShareAlike 4.0 International License
\end{abstract}

\begin{abstract}
This article described the constitutional prohibition for female Civil Servants (PNS) to get marry polygamically which is contained in the Government Regulation No 45 of 1990 in terms of the objectives of Islamic law (Al-Maqashid Al-Syariah). Civil servants as the subjects of this research are the civil servants in Konawe, Southeast Sulawesi. Based on the research focus, the research question was how was Al-Maqasid Al-Syariah on the implementation of Government Regulation No 45 of 1990 regarding the prohibition for female civil servants to become a second wife or more in Konawe? This research used a qualitative approach, while the data collection techniques used indepth interviews, participatory observation, and documentation. This research found that from the perspective of Al-Maqashid Al-Syariah female civil servants in Konawe, Southeast Sulawesi including their children tend to experience disadvantages. The preservation of religion, soul, mind, property, and offspring will not be fully maintained and fulfilled. It means that the harm of a polygamous family is more significant than its benefit. Therefore, female civil servants are more likely to build polygamous families when they are forced to.
\end{abstract}

Keywords: Polygamous, Al-Maqashid Al-Syariah, and Civil Servants

\section{A. Introduction}

This article described the constitutional prohibition for female civil servants (PNS) to perform a polygamous marriage. This rule is contained in government regulation no 45 of 1990 concerning amendments to government regulation no 10 of 1983 concerning marriage and divorce permits for civil servants. A lot of research has emerged discussing and implementing government regulation, such as Budiharjo's research which emphasized the polygamy dimension of civil servants. This research concluded that civil servants can practice polygamy while still referring to the benefit 
of their families ${ }^{1}$. Musgamy's research focused on the dimensions of marriage and divorce permits according to government regulation in gender equality2 ${ }^{2}$ Even Rosita \& Akim's research studied the analysis of the prohibition of polygamy as a second wife or more for female civil servants in terms of Islamic law ${ }^{3}$.

This research also indicates a prohibition on female civil servants from becoming a second wife or more due to the impact of polygamy disadvantages for family members. This regulation has a close relationship with the religious/spiritual dimension. Thus, the assumption is that family members are involved in the physical size and the spiritual dimension. Through happy families ${ }^{4}$, civil servants including in Konawe, Southeast Sulawesi will be more maximised in carrying out their duties and functions. Therefore, regulation on marriage and divorce permits for civil servants aims to protect civil servants themselves. In Cahaya's research, it is said that the prohibition aims to create benefits for civil servants 5 . However, other research states that several provisions (in the regulation) are deemed unfair for female civil servants because she is the second wife or more ${ }^{6}$.

Indeed, the construction of the prohibition refers to the objective that is realized in achieving justice for all parties. It is in this context that Kansil's view matches the terms of reference. He explained that the purpose of the law is to ensure legal certainty in society and that law must also be based on justice, namely the principles of justice from the community itself 7 . Even in Muhibbuthabry's research, it is said that this spirit is basically to protect and improve the position of women ${ }^{8}$. Meaning that the ideals of the regulation are constructed based on social justice, and legal purposes should be supported by three fundamental values, namely: justice, benefit, and legal certainty. However, the judge must pass through the social dynamics of a constantly moving society ${ }^{9}$.

Likewise, the dynamics of the implementation of government regulation no 45 of 1990 in Konawe cannot be separated from the framework of justice. For example,

${ }^{1}$ Eko Wahyu Budiharjo, "Praktik Poligami Pegawai Negeri Sipil Ditunjau Dari Sistem Hukum Perkawinan," Pandecta: Jurnal Penelitian Ilmu Hukum 8, no. 1 (2013): 67-74.

2 Awaliah Musgamy, "Menakar Batas Kesetaraan Gender Poligami Dalam PP No. 45 Tahun 1990 Tentang Izin Perkawinan Dan Perceraian Bagi PNS," al-Daulah: Jurnal Hukum Pidana dan Ketatanegaraan 6, no. 2 (2017): 395-404.

${ }^{3}$ Emi Yulia Rosita and Sulton Akim, "Kajian Yuridis Tentang Larangan Wanita Sebagai Istri Kedua Atau Lebih Menjadi Pegawai Negeri Sipil Dalam Perspektif Hukum Perkawinan Islam," Fairness and Justice: Jurnal Ilmiah Ilmu Hukum 6, no. 2 (2016): 153-164.

${ }^{4}$ Idi Warsah, "Dimensions Of Soul In The Quran: An Islamic Psychological Perspective," AKADEMIKA: Jurnal Pemikiran Islam 25, no. 2 (2020): 295-314.

${ }^{5}$ Nyr Cahaya, "Sanksi Pelaku Poligami Di Indonesia Perspektif Fiqh," Jurnal Hukum Islam 17, no. 1 (2017): 74-88.

${ }^{6}$ Nur Khoirin YD, "Menyoal Izin Poligami Bagi PNS," Yin Yang: Jurnal Studi Gender \& Anak 5, no. 2 (2010): 227-242.

7 C.S.T. Kansil, Pengantar Ilmu Hukum Dan Tata Hukum Indonesia (Jakarta: Balai Pustaka, 1994), 40.

8 Muhibbuthabry, "Poligami Dan Sanksinya Menurut Perundang-Undangan NegaraNegara Modern," Ahkam: Jurnal Ilmu Syariah 16, no. 1 (2016): 9-20.

9 Faisal, Pemaknaan Hukum Progresif: Upaya Mendalam Pemikiran Satjipto Rahardjo (Yogyakarta: Thafa Media, 2015), 21. 
before the enactment of government regulation, female civil servants may be used as second wives or more on the other hand, after government regulation was enacted, female civil servants were strictly prohibited from becoming second wives or more. However, in fact in Konawe, several female civil servants become second wives or more. If this phenomenon is viewed from a positive legal aspect, these civil servants have violated statutory regulation. But if it is understood from the perspective of Islamic law, these civil servants may become second wives or more while adhering to specific terms and conditions.

The opening of this opportunity indeed contains certain wisdom or purpose behind it. That is, every legal regulation has a sense, this is commonly known as almaqashid al-syariah ${ }^{10}$. Therefore, it is like the conclusion of Maggalatung's research that it is necessary to understand and explore the legal values that live in the community in realising justice in society ${ }^{11}$. Hence, the existence of regulations (read: the law) should try to bring out justice and bring benefits. In this context, government regulation no 45 of 1990 needs to be seen from the usefulness framework (sociological reality), which is strongly tied to legal values in the community of female civil servants.

Based on this framework, the researcher focused on conducting an in depth critical study of the prohibition for female civil servants to become second wives or more based on government regulation no. 45 of 1990 viewed from the perspective of almaqashid al-syariah ${ }^{12}$. Based on the focus of this research, the question in this research is: how effective is the implementation of government regulation no 45 of 1990 regarding the prohibition for female civil servants of becoming second wives or more from the perspective of al-maqasid al-syariah in Konawe? Therefore, this research used qualitative as a research approach, while the data collection techniques used in depth interviews, participatory observation, and documentation. All informants/participants of this research are female civil servants who have undergone polygamy.

\section{B. The Effectiveness of the Implementation of Government Regulation No 45 of 1990}

Government regulation no 45 of 1990 prevents female civil servants from being polygamous. However, it does not close the door to polygamy tightly, as it can be carried out under stringent conditions. The accounts of one of the informants explained that:

Polygamy is a serious matter; thus, even if civil servants want to do polygamy, it is not as fancy/happy as I have imagined. Civil servants are regulated to have only one wife, and the State only recognizes civil servants who have one wife. If a civil servant has more than one wife, the second wife does not receive allowances, either the ASKES allowance

10 Nurhadi, "Concept Of Maqasyid Syariah Family Sakinah In The Al- Misbah Tafsir By Muhammad Quraish Shihab," Akademika 24, no. 1 (2019): 165-186.

11 A. Salman Maggalatung, "Hubungan Antara Fakta, Norma, Moral, Dan Doktrin Hukum Dalam Pertimbangan Putusan Hakim," Jurnal Cita Hukum 2, no. 2 (2014): 185-192.

12 Candra Boy Seroza and Ahmad Hasan Ridwan, "Maqâshidî Interpretation; A Study On Interpretation Of Ahkam Verses In The Application Of Maqâshid Asy-Syarîah," Akademika 25, no. 1 (2019): 91-116. 
(health assurance) or the wife's card, as the first wife got ${ }^{13}$.

Therefore, civil servants who are polygamous need to obtain permission from a competent official. Viewed from the content, the existence of this regulation is a significant stumbling block for civil servants to practice polygamy. One of the informants stated that:

The polygamy regulations are designed in such a way only so that civil servants do not do polygamy. In Indonesia, polygamy for civil servants is given specificity; besides, some provisions generally apply to the community. Therefore, besides fulfilling the general conditions that apply to it, civil servants should also fulfill this specificity. This specificity is based on the idea that civil servants are state servants expected to become role models in society ${ }^{14}$.

This indicates that polygamy is a complicated thing, even though it is almost impossible to be done procedurally. This regulation is also a guide and a deterrent to female civil servants from becoming second wives or more. This complicated arrangement is felt by one of the informants when arranging her divorce. She said that:

In the past, when I wanted to take care of my divorce from my first husband, I had to get permission or a certificate from my boss first. It is said that civil servants, as plaintiffs or defendants, must submit a request in writing. In the letter requesting a divorce suit, we must write down all the reasons we want to divorce. Everything that is based on it must be complete ${ }^{15}$.

Tragically again, wages will not be given to the ex-wife if the reason for the divorce is due to the wife has committed adultery, committing cruelty, or physical and mental abuse to her husband. Alternatively, the wife has left her husband for two consecutive years without permission and valid reasons. On the other hand, if the wife asks for a divorce because she is becoming second wives or more, the husband commits adultery, commits cruelty, or physical and mental abuse. One of the informants stated that:

An official who receives a request for permission to marry more than one wife is obliged to pay close attention to the reasons stated in the letter of the demand for approval and the considerations of the heads of the Civil Servant concerned ${ }^{16}$.

The regulations regarding marriage, polygamy and divorce for civil servants in government regulation no 45 of 1990 and also government regulation no 10 of 1983 are the same. One of the informants stated:

If a civil servant wants to have more than one wife, he must first obtain permission from an authorized official or leader. Meanwhile, female civil servants are not allowed to become second wives. Requests for permission made by civil servants who wish to apply for polygamy must be submitted to officials through written authorisation and must be accompanied by complete reasons ${ }^{17}$.

Permission to have more than one wife can only be given by the official if it meets at least one alternative requirement and the three cumulative requirements. The alternative conditions include: the wife cannot fulfill her obligations, the wife has a disability or an incurable disease, or the wife cannot bear offspring. While the

\footnotetext{
13 "Results of Interviews with Polygamists (PNS B)," .

14 "Results of Interviews with the Heads of the KUA, Wonggeduku District," .

15 "Results of an Interview with the Wife of the Polygamist (PNS A),".

16 "Results of Interviews with the Heads of the KUA, Pondida District" .

17 "Results of Interviews with the Heads of the KUA, Wonggeduku District."
} 
cumulative requirements are a written consent from the wife, the civil servant has sufficient income to finance more than one wife as evidenced by an income tax certificate, a written guarantee that he will treat his wives fairly. As stated by the informant:

The authorized official cannot permit the marriage of more than one wife if it is contrary to the civil servant's beliefs or religious regulations. The union does not fulfill one of the alternative or cumulative requirements. It is against the laws and regulations apply, the reasons stated are contrary to common sense, or there is the possibility of interfering with official duties 18 .

Civil servants who violate government regulation are subject to administrative sanctions. In Article 45 in government regulation 9 of 1975, it is stated that if a civil servant commits polygamy without court permission often referred to as illegal polygamy (under the hands or Siri marriages) he will be threatened with a fine of up to Rp.7,500.00 (seven thousand five hundred rupiahs). As for the officer registering illegal polygamy, he is punished with a maximum imprisonment of three months or a maximum fine of Rp.7,500.00 (seven thousand five hundred rupiahs). In this context, it should be noted that the nominal value was very high when the regulation was enacted. Even another severe sanction is threatened with the sanction of dismissal. This is contained in Article 16 in government regulation 10 of 1983. It states that civil servants who violate the provisions of Article 3 paragraph 1 and Article 4 paragraphs 1,2 , and 4 will be subject to disciplinary action. These sanctions take the form of dishonourable dismissal, and these sanctions are not at their request.

This provision also applies to female civil servants, thus the regulation contained in government regulation also prohibits them from becoming second wives or more. Therefore, article 11 in government regulation 10 of 1983 regulates that the permit for female civil servants to become second wives or more is abolished by government regulation 45 of 1990. The implication is, female civil servants who practice polygamy without court permission are subject to imprisonment or a fine. This means that male and female civil servants have the same rules and regulations (in prohibiting polygamy) and the same sanctions.

Interestingly, the complicated procedures and requirements to carry out polygamy have succeeded in suppressing polygamy in minimal quantities. This means that in Konawe, Southeast Sulawesi, it is rare to find civil servants who foster families with polygamous nuances. Therefore, it can be said, the target aimed with the enactment of government regulation, which wants to limit or eliminate polygamy, can be practised massively. It can also narrow the space for movement "the might of male civil servants" to appear in polygamous behavior.

However, on the other hand, concerns arise, especially regarding preserving selfrespect and good morals. Why is it so? Some people choose shortcuts in practising polygamy, namely: illegal polygamy or uncontrolled Siri marriage. The difficulty of having polygamy permits is also suspected of contributing to infidelity and adultery by irresponsible married men, which are strictly prohibited by religious and moral

18 "Results of Interviews with the Heads of the KUA, Unaaha District" . 
laws. The affair will be easier to happen in the era of advances in communication technology today. Surprisingly, news of an experience is entertainment that is served by the media every day. This should be a concern for everyone to find the best solution. In this case, regulations concerning simpler and faster polygamy permit for a healthy solution are highly needed.

\section{Implementation of Government Regulation No 45 of 1990 from The Perspective of Al-Maqasid Al-Syariah}

Ideally, civil servants as elements of the state apparatus must be good role models for society, especially in the aspects of behaviour, action, and obedience to the prevailing laws and regulations, including in the administration of family life ${ }^{19}$. To implement this aspect, civil servants need to be in a conducive environment and not too disturbed by their family problems. That is, the psychological dimension of civil servants is very decisive on performance and harmony between behaviour and legislation.

Therefore, this condition needs attention through statutory regulations because one of the civil servants stated that sanctions in disciplinary punishment such as disrespectful dismissal of civil servants did not necessarily solve the problem ${ }^{20}$. If this pattern occurs, it will only drop the "authority" of the law itself. In line with the statement in the law, "the more negative sanctions are imposed on lawbreakers, this shows that the law's authority has decreased and is not effective in society". Likewise, in the middle of the Konawe community, the rules in government regulation no 45 of 1990 shows high authority. However, it is necessary to know the position of authority, especially if it is seen as violating it. In this context, it is also essential to look at the implications of violations in guarding and maintaining al-ushul al-khamsah, the Islamic law's objectives.

\section{Preservation of Religion}

To analyze the law of polygamy based on al-maqashid al-syariah, it is necessary to first know the basic commands of polygamy itself. All scholars (jumhur ulama) from the classical to the modern era agree that the main requirement of polygamy is justice as demanded by Qur'an. Although using different bases (arguments) in determining the law of polygamy, traditional scholars admit that legal polygamy is permissible it is not recommended (sunnah) or even obligatory (amr/order) as some people assume. Meanwhile, contemporary scholars tend to prohibit (forbid) polygamy, but they still open up the possibility to allow it.

Those who allow polygamy believe that the just requirements demanded by the Qur'an are only physical. In contrast, those who tend to prohibit it are because the justice must exist is psychological (heart), and it is difficult to realize. The emergence of this reason cannot be separated from the verses in the QS. An-Nisa verse 129. In

19 Choirul Mahfud, "Imagined Islamic Societies And The Role Of Ulema In Contemporary Indonesia," AKADEMIKA: Jurnal Pemikiran Islam 24, no. 02 (2019): 269-278.

20 "Results of Interviews with Polygamists (PNS B)." 
Darmawijaya's research, it is said that when the door to polygamy is closed tightly, women's benefit is maintained. Still, there is an open disadvantage: if there are men who want offspring, it will be difficult because their wives are barren ${ }^{21}$.

Based on the dynamics of polygamy carried out by civil servants, it turns out that justice is manifest only physically. However, this condition certainly has negative implications; as explained by the informant:

I do not have my marriage book. I always look for someone who can help me get a marriage book, but it does not exist yet. That is why I realized that a husband who has more than one wife is obliged to share the night fairly, but I understand that I am the second wife. The important thing is I can still take care of the children ${ }^{22}$.

Thus it is clear that polygamy justice is demanded physically, but at the same time, it is also closely related to the psychological dimension. Meanwhile, psychological livelihood itself has relevance to matters of the heart; then, in this context, it is the justice of physical and the spirit that needs to be reconciled. In Cahyani's research, it was concluded that polygamy is realized based on benefiting women ${ }^{23}$. This has been understood by the Konawe Civil Servants; such as the narrative of the informant that explained:

Responding to the practice of polygamy deviations, especially with wives who are civil servants, if we look at the framework of the maqashid al-syariah approach, it is necessary to look at the purpose of marriage, namely: sakinah, mawadah, and rahmah (a family with tranquillity, love, and mercy). And the purpose of polygamy is basically to provide benefits for humans, especially women and children ${ }^{24}$.

All Islamic doctrine boils down to safeguarding and also maintaining the benefit of life which is commonly called the objective of syariah (sharia). This objective cannot be separated from the syariah taklif, which refers to the main objective of protecting the benefit of beings. This objective is also operationalized in three parts, among others: something that is dharury (primary), is in the hajjiy (secondary) level, or in that which is tahsiniy (tertiary). In the context of polygamy in Konawe, it tends to have negative implications such as socio-psychological pressure, the emergence of violence, and social problems. All these implications occur in women and children as well as in society. This implication arises due to the existence of an implicit objective that is reductive. Civil servants tend to forget the moral message of polygamy that has been ordered in Islam. One of them is to create a sakinah, mawadah and rahmah family. So that violations occur and create congestion in people's lives. Al-maqashid al-syariah is oriented to bring out the basic idea of applying Islamic law, to protect or guarantee the benefit and continuity of rights and obligations in the system of life. It is explicitly stated that:

Benefit in the context of human life, in Islamic law, can be equated with the demand for protection of the five most basic lives, namely protecting religion, soul, mind, offspring,

21 Edi Darmawijaya, "Poligami Dalam Hukum Islam Dan Hukum Positif: Tinjauan Hukum Keluarga Turki, Tunisia Dan Indonesia," Gender Equality: International Journal of Child and Gender Studies 1, no. 1 (2015): 27-38.

22 "Results of an Interview with the Wife of the Polygamist,".

${ }^{23}$ Andi Intan Cahyani, "Poligami Dalam Perspektif Hukum Islam," urnal al-Qadau: Peradilan dan Hukum Keluarga Islam 5, no. 2 (2018): 271-280.

24 "Results of Interviews with the Heads of the KUA, Wawotobi District," . 
and property. If one of the five is ignored, then we could be wrongdoers 25 .

Even as Muhyidin said in his research, the concepts of benefit and harm are closely tied to Islamic law in society ${ }^{26}$. In fact, in a polygamous marriage especially with a second wife who is bound by particular rules a man tends not to maintain his religion. One of the informants stated that:

Do not expect a polygamous man to show that he is polygamous to carry out the sunnah. It often happens because of "the mischief" of the man. If it is like this, then it is clear that there will be problems in the household. Not only that, but it also has a wrong impression on Islam. This is often used by infidels to slander that Islam is a religion that destroys the family ${ }^{27}$.

The informant's narrative is a fact that happened, and it was experienced by a civil servant who was deceived by a man who claimed to be single but turned out to have a wife. In the end, this female civil servant got pregnant out of wedlock, and she was forced to marry another man to save her good name.

\section{E. Preservation of Soul}

Guarding the soul also includes dharuriyatul al-khamsi, and religion will not be established if there are no souls to uphold it. Therefore, if human want to keep their faith, they must protect the souls who support religion. Likewise, religion also provides space for the benefit and guarding the soul. In Azisi's research, there is a conclusion that religion impacts mental health psychological harmony ${ }^{28}$. This means that the relationship between religion and soul is robust, and one aspect (namely religion) can influence a person's psyche.

Although polygamy is manifest legally, psychologically, women will be hurt to see their husbands have relationships with other women. One study revealed that wives in polygamous families experience depression and husband wife relationships are not harmonious ${ }^{29}$. Because polygamy in practice is very complicated ${ }^{30}$, the implication is that wives often do coping strategies that are oriented towards their emotions $^{31}$. Strangely, this feeling not only happened to the first wife but also to other wives. As one of the informants told the researcher:

A long time ago, when my husband's first wife found out that her husband had remarried me, she was confused about where to complain. Besides being confused, she is also ashamed of her neighbours, embarrassed by her family, and even ashamed of their children because she may not think she can serve her husband well ${ }^{32}$.

25 "Results of Interviews with the Heads of the KUA, Pondidaha District.,".

${ }^{26}$ Muhyidin, "Maqashid Al-Syari'ah (Tujuan-Tujuan Hukum Islam) Sebagai Pondasi Dasar Pengembangan Hukum," Gema Keadilan 6, no. 1 (2019): 13-32.

27 "Results of Interviews with the Heads of the KUA, Pondida District."

28 Ali Mursyid Azisi, "Peran Agama Dalam Memelihara Kesehatan Jiwa Dan Kontrol Sosial Masyarakat," al-Qalb: Jurnal Psikologi Islam 11, no. 2 (2020): 55-7.

29 Andriana Kurniawati, "Dampak Psikologis Kehidupan Keluarga Pada Pernikahan Poligami Unpublished" (Universitas Negeri Yogyakarta, 2013).

30 Dwi Anggun Lestari and Endang Sri Indrawati, "Meniti Takdir Poligami: (Interpretative Phenomenological Analysis Pada Pengalaman Kepuasan Pernikahan Suami Yang Berpoligami," Jurnal Empati 8, no. 3 (2019): 40-54.

${ }^{31}$ Ilmaniar Fitriani Dewi and Nurchayati, "Coping Strategy Pada Perempuan Yang Di Poligami," Character: Jurnal Penelitian Psikologi 6, no. 2 (2019): 1-12.

32 "Results of an Interview with the Wife of the Polygamist." 
Indeed, there is an assumption that the husband wife issue is very private. It should not be shared with other people, including parents. As a result, the wife often covers up and behaves as if nothing happened. Not a few of them blame themselves and consider themselves guilty. The wife's refusal to open up is a form of loyalty to the family to protect the family's good name, especially her extended family, and avoid society's stigma as an unhappy family. In the end, all frustration and sadness can only be buried alone and gradually, if not resolved, will cause all kinds of psychological or physiological disorders. This situation arises from the deep feelings of love from the wife and low selfesteem. One of the informants stated that:

Let me be the second wife, but I love my husband wholeheartedly. Only he Ji that i love. I hope that my husband is the same as me. Anyway, I do not want to feel inferior, especially when it comes to fulfilling his biological satisfaction. Nevertheless, many times I feel inadequate too ${ }^{33}$.

These feelings eventually become severe psychological problems, especially when she comes under pressure from her family. In fact, in Hikmah's research, polygamy is an arena of violence against women ${ }^{34}$. One other psychological problem is internal conflicts within the family, such as conflicts between wives, wives with stepchildren, or other children with different mothers. There is even a sense of unhealthy competition between wives, so they fight to be the best. This is what Faruk said as women momeni lupus ${ }^{35}$. Thus, this dynamic shows how intense the conflict between the wives is. While the law is applied, strong women will beat weak women even though their fight gets more attention from their husbands. However, the wives' activities do not show their function as the subject of the woman herself. Instead, she strives to be an object for men by positioning herself to be the most attractive, kind, and attractive to her husband. The informant stated that:

Until now, I have never talked to my husband's first wife. She is still angry, maybe with me, even though I have been married for a long time. This also sometimes makes me think that it is better if I take care of the kids myself. I want to divorce. I can support my children even though my husband does not help. Instead of reporting to me and finally being fired from the civil servants, it was even worse. Why is that the rule that limits people from getting married? It is also up to God to want our love for our soul mate. With men who already have wives, what can we do?36.

Of course, this dynamic will gradually cause serious social problems in the Konawe people. Polygamous marriage also harms the mental development of children, especially girls. Thus, polygamous marriage carries a psychological burden, and this was indicated in Aditi's research ${ }^{37}$. The feeling of embarrassment when her father was called the bride and groom created a sense of insecurity so that he continued to avoid

33 Ibid.

34 Siti Hikmah, "Fakta Poligami Sebagai Bentuk Kekerasan Terhadap Perempuan," Sawwa 7, no. 2 (2012): 1-20. 2000).

35 Faruk, Women Momeni Lupus: Kumpulan Esai Sosial Budaya (Magelang: Indonesia Tera,

36 "Results of an Interview with the Wife of the Polygamist from PNS I,".

37 I Gusti Ayu Aditi, "Perkawinan Poligami Dan Pengaruh Psikologis Terhadap Istri, Anak Pada Keluarga Hindu Di Kota Mataram," Widya Kerta: Jurnal Hukum Agama Hindu 2, no. 1 (2019): 1-13. 
associating with his peers. Tragically, they seek other escape, such as drugs, promiscuity, and other negative behaviours. This happens because they do not get enough attention from their parents, especially their fathers, who are supposed to divide their time with other wives, or because the child never communicates with his father. This will result in children's psychological pressure, which weakens their physical condition to be susceptible to various diseases.

\section{F. Preservation of Mind}

Apart from preserving religion and soul, Islamic law is also oriented to maintain the existence of the mind. If this orientation is not heeded, it will threaten the attitudes and actions of human beings. Therefore, Islam recommends studying science and developing it. Furthermore, Islam ordered to refrain from fantasizing or listening to something that is not useful. In this context, the guardian of mind occupies a strategic position in people's lives, because God gives guidance to humans ${ }^{38}$.

However, polygamy has implications for the emergence of psychological problems for children and women. As Wardani \& Hasanah's research concludes, one of them is the decline in the relationship between father and son ${ }^{39}$. As the informant said:

Sometimes I get stressed when I remember my second wife's status as a civil servant, worried that nothing is behind. I also heard that my children and the children of my husband's first wife seemed to be neglected in their relationships. How naughty. Likes to drunk. Even though $i$ always remind my husband to pay attention to his children there too ${ }^{40}$.

It has various kinds of irregularities in polygamy because it has become a prevalent trend in the Konawe people. Although on the one hand, it hurts the rate of the intellectual development of children. Syarifuddin's research conclusions also state that the determinant factors that negatively affect the academic aspect are parenting and full attention from parents, especially mothers ${ }^{41}$. Female civil servants (read: the wife/mother) the first school (read: the beginning) not very effective and significant to children's education.

On the other hand, children's intellect is not prioritized due to polygamy actors who do not understand the game's rules or the conditions for its permissibility. More than that, polygamy often leaves grief for female civil servants so that they no longer focus on children's psychological and physiological development. As a result, women are helpless with the psychological and sociological conditions that place them as "must lose" objects. Hafidzi \& Hayatunnisa's research also concluded that polygamy harms women ${ }^{42}$.

${ }^{38}$ Norhasanah, "Pengaruh Konsep Akal Dalam Pengembangan Pendidikan Islam," Nalar 1, no. 2 (2017): 138-145.

${ }^{39}$ Ratna Kusuma Wardani and Idaul Hasanah, "Pemenuhan Hak Anak Dalam Keluarga Poligami," Jurnal Perempuan dan Anak 1, no. 1 (2015): 1-6.

40 "Results of an Interview with the Wife of the Polygamist from PNS 3,".

${ }^{41}$ Syarifuddin, "Prestasi Peserta Didik Pada Keluarga Berpoligami Di SMK Negeri 6 Takalar" (Universitas Negeri Makassar, 2019).

42 Anwar Hafidzi and Eka Hayatunnisa, "Kriteria Poligami Serta Dampaknya Melalui Pendekatan Alla Tuqsitu Fi Al-Yatama Dalam Kitab Fikih Islam Wa Adillatuhu," Syariah: Jurnal Hukum dan Pemikiran 17, no. 1 (2017): 64-85. 


\section{G. Preservation of Property}

In the Konawe, most polygamy is carried out without administrative registration known as an underhand marriage. This type of marriage is not registered at the marriage registry office or the Office of Religious Affairs (KUA) for Muslims or the Civil Registry Office (KCS) for non-Muslims. It is almost certain that only a handful of polygamous marriages were legally recorded. They feel no need for a marriage certificate because he already has the certificate with his first wife. One informant stated that:

The problem is that married wives without registration at a State institution (KUA) or who do not have a Marriage Certificate are not legally valid. Therefore, they cannot claim their rights, such as rights to maintenance, inheritance, property, and guardianship rights, especially if the husband dies ${ }^{43}$.

According to Article 6, paragraph 2 of the Islamic Law Compilation, their marriage is not legally enforceable. Based on this fact, there are cases where women are abandoned after being divorced or their husbands die. Moreover, they do not have the right to inherit or provide a living from their husbands because they are not legally valid wives. Therefore, it is reasonable if most female civil servants are abandoned by their husbands without going through the legal process in court and without any guarantee.

Apart from that, underhand marriage also has a social impact on women. It is difficult for her to socialize with community members because they are considered mistresses or cohabiting (living in a house without being married). This is consistent with the informant's statement that:

I always feel that my life is not every day. I always think that I am with my husband as an illegitimate partner. Even though there is a marriage book, I can change my identity. Even though the husband spent more nights here, he did not meet the money he needed for his daily needs. Nevertheless, it is okay because I have my salary, unlike his first wife. Nonetheless, he should do justice, which is fair to my daily needs and my children because my children also need school fees, including the day's ratio for the night ${ }^{44}$.

The problem of love or human feeling that Allah gives is understandable because humans will not just love someone the same as others. After all, this is under human ability. However, it should be applied relatively in polygamy in terms of giving material or money because it is accessible to humans, therefore, polygamy is very difficult in the Religious Courts. It maintains a cautious attitude to be fair. According to the author, husbands have not been able to apply a fair attitude in distributing income for their wives. Because the work carried out by polygamous husbands has a non permanent income, resulting in not spreading money consistently and in physical conditions that cannot fulfill their wives' overnight shift. Whereas in Islamic law, the scholars of Imam Hanafi, Maliki, Hambali, and Shafi'i have different opinions but have the same intention: a polygamous person is obliged to be fair.

Husbands must be fair in all things. Is it OK to provide a living or fair in biological needs? If there is an inheritance, he must also remember me. Although I am the second

\footnotetext{
43 "Results of Interviews with the Heads of the KUA, Pondidaha District."

44 "Results of an Interview with the Wife of the Polygamist from PNS 3."
} 
wife, there are our children. It is also applying to his first wife; he must be fair. If he has agreed with his wife and me, it can undoubtedly become two sakinah, mawaddah, and warahmah households ${ }^{45}$.

The rights and obligations between husband and wife are detailed in Islamic law. When a husband has more than one wife, he must fulfill the provisions in Islamic law, stipulating that he must support all his wives, both physically and mentally. In polygamy, the distribution of income is an important thing that must be fulfilled by husbands who practice polygamy, namely payment in the form of money or income in the form of a turn or giving a night's ration.

In Konawe, the author found a reality of a husband who practices polygamy but cannot support the family. His wives provide for him and support the family. Because the husband cannot meet the family's needs because he does not have a permanent job, the wife replaces the role of the family in fulfilling a living. Meanwhile, according to Islamic law, the wife's right is that every polygamous wife, siri or not, has the same rights starting from the time the marriage contract is carried out.

There is no difference between a wife whose marriage is recorded at the Office of Religious Affairs and a Siri wife (her marriage is not registered at the Office of Religious Affairs). It has the same rights to clothing, food, shelter, residence, and other regarding material matters. However, if the wife has the nusyuz attitude, she will lose all her rights as a wife because nusyuz is an act of disobedience forbidden to every woman who does it. The reason for all of this is that because living and inheritance are the blessings of Allah, it is not justified to get them by way of disobedience and immorality.

\section{H. Preservation of Offspring}

Islam instructs its followers to be able to maintain offspring for the continuation of their life. In this context, Allah has arranged marriage contracts and rules related to marriage procedures. One of the stipulations stipulated that the marriage allowed in Islam is a marriage intended to produce offspring. This is very much the case for female civil servants in Konawe, especially for those who are concerned with family harmony. One of the informants stated that:

The presence of government regulation 45 of 1990, especially Article 4 paragraph 2, is very appropriate for female civil servants who should not be allowed to become second, third, or even fourth wives because, if they are allowed (to become second, third, or even fourth wives), it is feared that it will hurt family life. Make it very possible to have intrapersonal conflicts and difficult to foster a harmonious and happy family. Family members who are in conflict situations will grow into individuals who get psychological disorders. And this condition will (eventually) affect their behaviour and cause the duties assigned as civil servants to be disrupted ${ }^{46}$.

It is reasonable that state regulations are oriented towards the presumptions (assumptions) of the welfare of civil servants. However, when viewed from the framework of Islamic law, then the purpose of these rules (read: the teachings of Islam) leads to al-maqashid al-syariah. Likewise, in marriage, some female civil servants are

\footnotetext{
45 "Results of an Interview with the Wife of the Polygamist from PNS 1," .

46 "Results of Interviews with the Heads of the KUA, Wonggeduku District."
} 
aware that marriage must be rooted in the principle of justice. Reasonably, rules/norms which are enforced in the midst of society are not laws but benefit as a concrete form of al-maqashid al-Syariah or the morality of government regulation themselves. Therefore, the understanding government regulation that prohibits female civil servants from becoming second wives or more for the sake of benefit needs to be echoed.

This means that polygamous marriages that are not based on justice will only create conflict. Besides, it will also have an impact on the psychological development of children and their future. The information from the informants stated that:

In a disharmonious atmosphere, it will be challenging to have a good educational process. Thus the child's development leads to an unfavourable personal form. The negative consequences can be predicted. Namely, the child does not feel at home, loses selfconfidence, develops aggressiveness and hostility, and other abnormalities ${ }^{47}$.

The situation will be worsened when the child is put in an unsupportive environment, even though family life significantly affects the child's life journey and future. Muslifar's research concluded that family harmony is very influential on children's social behaviour ${ }^{48}$. Thus, the family is an arena for children to get their first education, both physically and spiritually. Therefore, family members need to recognize the form of problems in the family commonly called the family therapy perspective ${ }^{49}$.

It is reasonable that female civil servants consider polygamous marriages to be detrimental to women and children. If it is "harmful", then it can be said that it is not an embodiment of the objective of Islamic law related to allowing polygamy, even though parties who are disadvantaged (by polygamy) cannot be separated from the low morality of the people involved in polygamy. Polygamy is recognized by law, and the Compilation of Islamic Laws guarantees a more respectful family life compared to monogamy which degrades women and leaves their offspring stranded, even though the purpose of marriage is to protect the offspring (hifzhul nasl) ${ }^{50}$. Based on this context, one of the heads of the KUA (Religious Affairs Office) emphasized that:

Polygamy is not something that must be kept secret, but something that must be discussed, for example, if the husband wants to do polygamy because of something from his marriage, such as the wife is unable to give birth, the wife is nusyuz, the wife is sick and so on ${ }^{51}$.

This is different if the polygamous marriage is only driven by sex, which means that the doer belongs to people who follow lust. Nevertheless, this spirit cannot be hidden from God's supervision, as stated in QS. Al-Ankabut verse 52. This polygamous marriage does not have any sacred values that have theological nuances, quite the opposite, this polygamous marriage only has pragmatic biological values. For this

47 "Results of an Interview with the Wife of the Polygamist from PNS II,".

48 Rury Muslifar, "Pengaruh Keharmonisan Keluarga Terhadap Keluarga Sosial Anak," in Proceeding: 3rd Counseling Jamboree Year 2017, 2017, 62-65.

49 et al Syamsul Hadi, "Disharmoni Keluarga Dan Solusinya Perspektif Family Therapy:

Studi Kasus Di Desa Telagawaru Kecamatan Labuapi Lombok Barat," Tasamuh: Jurnal Komunikasi E Pengembangan Masyarakat Islam 18, no. 1 (2020): 114-137.

50 Wahyu Wibisana, "Pernikahan Dalam Islam," Ta'lim: Jurnal Pendidikan Agama Islam 14, no. 2 (2016): 185-193.

51 "Results of Interviews with the Heads of the KUA, Wawotobi District." 
reason, even though the situation is not harmonious, the husband will have difficulty divorcing his wife due to the husband's position. The latter does not have a solid reason to "truncate" the marital status.

Apart from these conflicts, marriage is indeed oriented to maintain and protect the stability of the order of life the damage and extinction of energy that needs to be avoided through the medium of marriage ${ }^{52}$. In polygamy, there are many family breakdowns, especially if a husband is too inclined towards one wife. The fate of the offspring will be neglected because they are not taken care of or noticed.

Therefore, in the family, the husband's position is very significant. If he does not provide the rights of his wife and children properly, then it is certain that the condition of the family will be chaotic. Female civil servants in this context are conscientious in deciding their marriage decisions because there are other impacts on the children born from polygamy marriage, namely their birth status cannot be registered as a legal child. The implication is that the child only has a civil relationship with the mother and the mother's family and does not have a legal relationship with the father. This condition is terrible socially and psychologically for the child and the mother. The unclear status of the child before the law results in the child not having the right to supports, inheritance, cost of living, and education from his father. This means that polygamy opens opportunities for children's futures to be bleak.

\section{Conclusion}

The effectiveness of the application of government regulation number 45 of 1990 concerning the prohibition of female servants from becoming second wives in Konawe can minimize polygamy. Even this practice is challenging to realize because it is almost impossible for civil servants to do polygamy both procedurally and openly. The existence of government regulation is indeed capable of building a "fierce" image. However, the indication is that it can effectively prevent female civil servants from becoming second wives and so on. Often, female civil servants in Konawe avoid polygamous marriages in fostering their household.

The implementation of government regulation from the perspective of almaqashid al-syariah indeed needs to be seen from the implications of the practice of its violations. Especially when viewed from the care and preservation of al-ushul alkhamsah (five objectives of Islamic law). In religious protection, polygamy is an emergency way that is very difficult to realize because it requires harsh conditions, namely, the requirement of justice. Moreover, the conditions for civil servants are legally bound by government regulations that prohibit it and the fact that economically, civil servants have limited income and according to applicable laws. Therefore, in the context of polygamy, civil servants are advised not to do it. Likewise, for mental care, most wife experiences depression, prolonged stress, sadness, and disappointment when she finds out that she has been betrayed. It is not uncommon in polygamous families that the dynamics of physical violence against wife and children

52 Mufliha Wijayati and Aden Rosadi, “Women Before The Law: Between Justice And Certainty: Notes On Divorce Settlement Case Due To Domestic Violence In Metro Religious Court," AKADEMIK 25, no. 01 (2020): 209-233. 
emerge. Judging from the reasoning preservation, female civil servants often experience stress and mental disorders in polygamous families.

In property preservation, often the husband in a polygamous marriage neglects to provide a living, even in the distribution and prosecution of the husband's inheritance, it raises disputes. Meanwhile, in the preservation of offspring, polygamous families are very vulnerable to negative impacts on the patterns of children's lives because the family is brutal to foster into a harmonious and happy family.

\section{REFERENCES}

Aditi, I Gusti Ayu. "Perkawinan Poligami Dan Pengaruh Psikologis Terhadap Istri, Anak Pada Keluarga Hindu Di Kota Mataram." Widya Kerta: Jurnal Hukum Agama Hindu 2, no. 1 (2019): 1-13.

Azisi, Ali Mursyid. "Peran Agama Dalam Memelihara Kesehatan Jiwa Dan Kontrol Sosial Masyarakat." al-Qalb: Jurnal Psikologi Islam 11, no. 2 (2020): 55-7.

Budiharjo, Eko Wahyu. "Praktik Poligami Pegawai Negeri Sipil Ditunjau Dari Sistem Hukum Perkawinan." Pandecta: Jurnal Penelitian Ilmu Hukum 8, no. 1 (2013): 6774.

Cahaya, Nyr. "Sanksi Pelaku Poligami Di Indonesia Perspektif Fiqh." Jurnal Hukum Islam 17, no. 1 (2017): 74-88.

Cahyani, Andi Intan. "Poligami Dalam Perspektif Hukum Islam." urnal al-Qadau: Peradilan dan Hukum Keluarga Islam 5, no. 2 (2018): 271-280.

Darmawijaya, Edi. "Poligami Dalam Hukum Islam Dan Hukum Positif: Tinjauan Hukum Keluarga Turki, Tunisia Dan Indonesia,." Gender Equality: International Journal of Child and Gender Studies 1, no. 1 (2015): 27-38.

Dewi, Ilmaniar Fitriani, and Nurchayati. "Coping Strategy Pada Perempuan Yang Di Poligami." Character: Jurnal Penelitian Psikologi 6, no. 2 (2019): 1-12.

Faisal. Pemaknaan Hukum Progresif: Upaya Mendalam Pemikiran Satjipto Rahardjo. Yogyakarta: Thafa Media, 2015.

Faruk. Women Momeni Lupus: Kumpulan Esai Sosial Budaya. Magelang: Indonesia Tera, 2000.

Hafidzi, Anwar, and Eka Hayatunnisa. "Kriteria Poligami Serta Dampaknya Melalui Pendekatan Alla Tuqsitu Fi Al-Yatama Dalam Kitab Fikih Islam Wa Adillatuhu." Syariah: Jurnal Hukum dan Pemikiran 17, no. 1 (2017): 64-85.

Hikmah, Siti. "Fakta Poligami Sebagai Bentuk Kekerasan Terhadap Perempuan." Sawwa 7, no. 2 (2012): 1-20.

Kansil, C.S.T. Pengantar Ilmu Hukum Dan Tata Hukum Indonesia. Jakarta: Balai Pustaka, 1994.

Kurniawati, Andriana. "Dampak Psikologis Kehidupan Keluarga Pada Pernikahan Poligami Unpublished." Universitas Negeri Yogyakarta, 2013.

Lestari, Dwi Anggun, and Endang Sri Indrawati. "Meniti Takdir Poligami: (Interpretative Phenomenological Analysis Pada Pengalaman Kepuasan Pernikahan Suami Yang Berpoligami." Jurnal Empati 8, no. 3 (2019): 40-54.

Maggalatung, A. Salman. "Hubungan Antara Fakta, Norma, Moral, Dan Doktrin Hukum Dalam Pertimbangan Putusan Hakim." Jurnal Cita Hukum 2, no. 2 (2014): 185-192.

Mahfud, Choirul. "Imagined Islamic Societies And The Role Of Ulema In Contemporary Indonesia." AKADEMIKA: Jurnal Pemikiran Islam 24, no. 02 (2019): 269-278. 
Muhibbuthabry. "Poligami Dan Sanksinya Menurut Perundang-Undangan NegaraNegara Modern." Ahkam: Jurnal Ilmu Syariah 16, no. 1 (2016): 9-20.

Muhyidin. "Maqashid Al-Syari'ah (Tujuan-Tujuan Hukum Islam) Sebagai Pondasi Dasar Pengembangan Hukum." Gema Keadilan 6, no. 1 (2019): 13-32.

Musgamy, Awaliah. "Menakar Batas Kesetaraan Gender Poligami Dalam PP No. 45 Tahun 1990 Tentang Izin Perkawinan Dan Perceraian Bagi PNS." al-Daulah: Jurnal Hukum Pidana dan Ketatanegaraan 6, no. 2 (2017): 395-404.

Muslifar, Rury. "Pengaruh Keharmonisan Keluarga Terhadap Keluarga Sosial Anak." In Proceeding: 3rd Counseling Jamboree Year 2017, 62-65, 2017.

Norhasanah. "Pengaruh Konsep Akal Dalam Pengembangan Pendidikan Islam." Nalar 1, no. 2 (2017): 138-145.

Nurhadi. "Concept Of Maqasyid Syariah Family Sakinah In The Al- Misbah Tafsir By Muhammad Quraish Shihab,." Akademika 24, no. 1 (2019): 165-186.

Rosita, Emi Yulia, and Sulton Akim. "Kajian Yuridis Tentang Larangan Wanita Sebagai Istri Kedua Atau Lebih Menjadi Pegawai Negeri Sipil Dalam Perspektif Hukum Perkawinan Islam." Fairness and Justice: Jurnal Ilmiah Ilmu Hukum 6, no. 2 (2016): 153-164.

Seroza, Candra Boy, and Ahmad Hasan Ridwan. "Maqâshidî Interpretation; A Study On Interpretation Of Ahkam Verses In The Application Of Maqâshid AsySyarîah." Akademika 25, no. 1 (2019): 91-116.

Syamsul Hadi, et al. "Disharmoni Keluarga Dan Solusinya Perspektif Family Therapy: Studi Kasus Di Desa Telagawaru Kecamatan Labuapi Lombok Barat." Tasamuh: Jurnal Komunikasi \& Pengembangan Masyarakat Islam 18, no. 1 (2020): 114-137.

Syarifuddin. "Prestasi Peserta Didik Pada Keluarga Berpoligami Di SMK Negeri 6 Takalar." Universitas Negeri Makassar, 2019.

Wardani, Ratna Kusuma, and Idaul Hasanah. "Pemenuhan Hak Anak Dalam Keluarga Poligami." Jurnal Perempuan dan Anak 1, no. 1 (2015): 1-6.

Warsah, Idi. "Dimensions Of Soul In The Quran: An Islamic Psychological Perspective." AKADEMIKA: Jurnal Pemikiran Islam 25, no. 2 (2020): 295-314.

Wibisana, Wahyu. "Pernikahan Dalam Islam." Ta'lim: Jurnal Pendidikan Agama Islam 14, no. 2 (2016): 185-193.

Wijayati, Mufliha, and Aden Rosadi. "Women Before The Law: Between Justice And Certainty: Notes On Divorce Settlement Case Due To Domestic Violence In Metro Religious Court." AKADEMIK 25, no. 01 (2020): 209-233.

YD, Nur Khoirin. "Menyoal Izin Poligami Bagi PNS." Yin Yang: Jurnal Studi Gender $\mathcal{E}$ Anak 5, no. 2 (2010): 227-242.

"Results of an Interview with the Wife of the Polygamist," n.d.

"Results of an Interview with the Wife of the Polygamist (PNS A)," n.d.

"Results of an Interview with the Wife of the Polygamist from PNS 1," n.d.

"Results of an Interview with the Wife of the Polygamist from PNS 3," n.d.

"Results of an Interview with the Wife of the Polygamist from PNS I," n.d.

"Results of an Interview with the Wife of the Polygamist from PNS II," n.d.

"Results of Interviews with Polygamists (PNS B)," n.d.

"Results of Interviews with the Heads of the KUA, Pondida District" (n.d.).

"Results of Interviews with the Heads of the KUA, Pondidaha District.," n.d.

"Results of Interviews with the Heads of the KUA, Unaaha District" (n.d.).

"Results of Interviews with the Heads of the KUA, Wawotobi District," n.d.

"Results of Interviews with the Heads of the KUA, Wonggeduku District," n.d. 